\title{
The Importance of Innovation in the Development of Polish Business Gazelles ${ }^{1}$
}

\author{
Agnieszka Kuś ${ }^{2}$
}

Submitted: 9.11.2019. Accepted: 6.02.2020

\section{Abstract}

Purpose: To assess the level of innovativeness of modern enterprises and identify the supporting factors to implement the innovative processes.

Methodology: Research using the Computer Assisted Web Interviews was conducted according to the guidelines of the research procedure of the creators of innovation audit, i.e. J. Tidd and J. Bessant. The electronic questionnaire was sent to selected 110 enterprises from the SME sector in December 2018.

Findings: The innovation activities implemented by companies are highest rated the most by owners of small service firms belonging to the ICT sector. Definitely more actions are taken in terms of strategy and organization, and the least attention is paid to relationship.

Limitations: The presented considerations based solely on the quantitative analysis of the part of the population of Polish business gazelles, which does not exhaust the discussed issues. The presented method is only a general outline of the current situation in each company based on the declarative indications of their owners regarding the use of innovation.

Originality: Currently, the role of innovation is so significant that the economic environment considers it one of the key determinants for the development of enterprise competitiveness. The first part of the paper is devoted to the description of innovation concepts in the main interpretative areas. The second part presents the results of empirical research on the assessment of organization innovation level according to five separate areas among Polish Business Gazelles.

Keywords: innovation audit, business gazelles, SME sector innovativeness

JEL: 030, 31, L25

This research was funded from an individual faculty grant entitled "Innovation of contemporary organizations and applied development strategies" with the number 1218-E, awarded in 2018 by the Dean of Faculty of Economic Sciences and Management at the Nicolaus Copernicus University in Torun.

2 Nicolaus Copernicus University in Torun, Faculty of Economic Sciences and Management, Department of Enterprise Management, 11 Jurija Gagarina St., 87-100 Torun, e-mail: adk@umk.pl; https://orcid.org/0000-0003-1098-7526. 


\section{Introduction}

Besides knowledge and information, innovativeness now completes the triad of growth and development of enterprises, regions, economies, and even entire civilizations. In the era of strong market competition, the ability of business entities to create and absorb innovative solutions in their operations and the ability to conduct research and development (R\&D) activities are of particular importance to the organizational level. The current market realities associated with the growing consequences of globalization processes oblige entrepreneurs to reconsider their organizations' management systems and further expansion perspectives. Moreover, running a business carries a lot of different challenges, from the creation of a comprehensive strategy that includes the needs of various stakeholder groups through the act of an entity in a dynamic environment to systematic actions that stimulate internal knowledge and creativity resources to make better process solutions or organizational functions. Innovation in enterprises is useful to enhance the existing assortment offer with new products, increase the level of quality of services, gain new markets, introduce innovative technological solutions in production processes, or apply solutions or marketing other than management. The motives for undertaking and conducting innovative activity by individual business entities are diverse, but their goals are often convergent: achieving profit, the possibility of organization development, gaining lasting market advantages, and surviving in a turbulent environment. The innovative activity should become the main driving force of every enterprise, especially for Small and Medium-sized Enterprises (SMEs), and it should be inscribed in its organizational culture and management systems. Therefore, it is not surprising that innovations are sought after and desired in almost every dimension of socio-economic life. "Since innovation is the driving force of modern economies, appropriate institutional conditions should be ensured to foster creativity. It is a prerequisite for maintaining the pace of economic modernization and improving the living standards" (Wildowicz-Giegel, 2012).

The main goal of the current article is to assess the level of innovativeness of modern enterprises and identify the factors supporting the implementation of innovative processes. The first part is descriptive and shows the dominant aspects of innovation perception over the last years, but also contains their concise characteristics. The second part covers the results of empirical research in the innovation audit of Polish business gazelles, which in my opinion create the added value of this work. The completed research is to provide companies from the Business Gazelles group with valuable information on key areas that stimulate their innovation. Moreover, the article seeks to indicate the areas that require more attention for them to function even better in the modern market. 


\section{Understanding Innovation in Selected Theoretical Approaches}

The term "innovation" is, in principle, associated with a kind of novelty, with a significant improvement of the current state of affairs, or with change; therefore, it has a positive overtone. Despite the popularity or even "ubiquity" of innovation in many areas of life, it is a new concept whose scope has not yet been systematized, and meaning has not been clearly interpreted (Jurczyk-Bunkowska, 2014). However, there is growing interest in the issues of innovation even in the environment of scientists, who at the beginning of the twenty-first century published only about 100-200 publications devoted to this subject; much less than in the following decade, when scholars published twenty times more texts about innovation (Open Science Centre, 2018). There are many broad and narrow definitions of innovation in the literature. However, most agree that the concept has evolved over the years, trying to reflect the essence and scope of innovation adequate to the conditions and needs of the economy. Drucker (1994) states outright that, "we cannot develop a comprehensive theory of innovation yet .... However, we know enough to find when, where and how to look for opportunities for innovation, and how to assess their chance of success or the risks that go with them. We know enough to develop, though still in outline, the practice of innovation."

We should seek the genesis of the word "innovation" in the Latin innovare, which means "to renew, to introducing something new, or to make specific reforms" (Tokarski, 1971). The signs of interest in the subject of discoveries, imitations, and technical progress - but also their impact on the organization of work or economic development - were shown by the classics of economics (see Ricardo, 1821; Mill, 1848; Say, 1855; Tarde, 1902; Smith, 1904; Marshall, 1920; Pigou, 1932) already at the end of the eighteenth century. However, the first reflections that form the basis for the development of theoretical innovation were presented by the French economist J.B. Say around 1800. In Say's opinion, the entrepreneur (the owner) creates the first link of the organization's innovation, because he or she is the one who decides about "transferring economic resources from the lower area to the area of higher productivity and the possibility of getting better property benefits" (Drucker, 1994). Regarded a precursor of the attribute of innovation in the literature, J.A. Schumpeter identifies the entrepreneur with an "actor" who, in pursuit of profit, implements innovative solutions by other (new) combinations of production means, "destroying" the existing system: the so-called creative destruction (Gust-Bardon, 2012). Schumpeter (1960) identifies innovation with the creation of new products or services, the implementation of new processes and new methods, and the acquisition of new markets, sources of resources, sales, or buying techniques. Schumpeter associates innovation with the first application of a solution, which confirms repeated use of the word "new" in the above definition. Due to the modern 
transition of many countries and the development of specific economic branches, innovation has expanded, and thus exceeded the technical sphere. As Niedzielski and Łobacz (2011) emphasize, "innovation was born in industry, and only the change of the economic system to one where services dominate or at least play an equal role, has caused the transfer of the phenomenon of innovation also for service activities."

The analysis of fifty definitions of innovation planned over the last few decades - both in international and Polish subject literature - illustrates the diversity of dominant aspects and the semantic interpretation of the entire nomenclature related to innovation. Figure 1 presents the eight main interpretative viewpoints on innovation.

Figure 1. Main interpretative areas of innovation

\begin{tabular}{|c|c|c|c|c|}
\hline Novelty & Modification & $\begin{array}{c}\text { Hybrid } \\
\text { approach }\end{array}$ & Process & $\begin{array}{l}\text { Practical } \\
\text { application }\end{array}$ \\
\hline & $\begin{array}{l}\text { The prism } \\
\text { of implication }\end{array}$ & $\begin{array}{c}\text { Humans' } \\
\text { ability to act }\end{array}$ & $\begin{array}{l}\text { The use } \\
\text { of knowledge }\end{array}$ & \\
\hline
\end{tabular}

Source: own elaboration of the subject literature.

One of the most common threads in the concept of innovation is the aspect of novelty. Besides Schumpeter, those who particularly emphasize innovation are Madej (1970) and Kotler (1999). For the former, innovations are "something new, any changes in relation to the existing state, regardless of their direction - although the lead to progress." The latter defines innovations similarly broad by saying that, "they refer to any good, service and idea that perceived by someone as a new." Besides, during the analysis of novelty perception in terminological terms, we may notice two main dimensions of the presented concepts: innovations as novelty for the organization adopting a solution (see Damanpour, 1991; Borins, 2002; Walker, 2006) or innovations as novelty created for the market (see Brown and Ulijn, 2004). In the case of novelties, innovations are also perceived by many authors as something new (see Barnett, 1953; Grudzewski and Hejduk, 2000; Rogers, 2003), the premise of creating a novelty (see Griffin, 1996; Niedzielski, 2003; Białon, 2010), or an instrument for creating new products (see Wandelt, 1972; Urabe, 1988; Żołnierski, 2005; Zastempowski, 2010).

A completely different view is presented by Webber (1996) for whom innovation is an improvement of production processes or technologies and modification of offered 
products and services. This definition does not include the aspect of novelty but only the introduction of significant changes in various areas.

In the second half of the twentieth century, most supporters had a "hybrid" approach, allowing for the perception of innovation as both new values and improved views of products, processes, or organizational systems (see Harman, 1971; Penc, 1999; Brzeziński, 2001). One of the more often mentioned representatives of this dimension of innovation concept is Porter (1990), for whom innovations are "both technological improvements and better methods, as well as ways to do things, and changes in products, processes, new approaches to marketing, new forms of distribution, or new management concepts."

Equally often, scholars identify innovation as a process (see Whitefield, 1979; Rothwell, 1986; Kotarba, 1987; Pomykalski, 2001; Witkowska and Wysokińska, 2006) that embraces many activities: from the creation of an idea through its implementation to its prevalence on the market. One of the more contemporary approaches to innovation as a process is presented by O'Sullivan and Dolley (2009) who - besides the process dimension and the aspect of novelty - address the type of innovations and the consequences of an innovative solution. In their book, they indicate that innovation is "the process of introducing large and small changes, radical and gradual in products, processes, and services. The result of these improvements is the introduction of something new, which increases the values for the customer and contributes to the growth of the organization's knowledge."

Moreover, others emphasize a definition of innovation as the practical application of resulting solutions (see Allen, 1966; Holstein-Beck, 1977; Freeman, 1997; Stamm, 2008). In 1974, Parker (1974) perceived innovation from the viewpoint of a "process involving all activities bringing a new product or method for practical use." Thirty years later, Bogdanienko, Haffer, and Popławski (2004) identified innovation as "the final stage in the creation of new material reality, it is the first application of new ideas in practice." Contemporary representatives of management sciences, Tidd and Bessant (2013), also call innovation a sequence of events, which result in an idea that finds a common practical application and brings several benefits to the organization.

Another approach to innovation is to perceive it through the prism of implications that it brings both to business entities and stakeholders. Advocates of this approach emphasize in the impact of innovations, among other things, on "increasing the usability, functionality and value of the organization" (Siau and Messersmith, 2003), "improving the results, efficiency, effectiveness and quality level of services provided” (Greenhalgh 
et al., 2004) and "creating new values for stakeholders of the enterprise" (Timmerman, 2009). Moreover, Kasprzyk (1980) attributes innovations to another feature, similar to the one discussed in the context of consequences, to the "previously unknown way of satisfying and creating new needs."

The aspect of perceiving innovation as an ability to act seems to be extremely important from the viewpoint of the growing role of the human factor in the development of contemporary organizations. Janasz (2005) directly emphasizes innovations as "a product of human invention, at the same time combining ingenuity and knowledge the possess." Other authors add that changes introduced by human activity liked to innovations should be intentional (Pietrasiński, 1970), consciously implemented (Drucker, 1994), and translatable into the progressive functioning of the organization (Więckowski and Pasieczny, 1981). Moreover, as Dolińska (2012) rightly indicates, for modern enterprises "heterogeneity in the portfolio of workers and collaborators is very important and they can learn from a wide stock of knowledge." In one of the recent publications, Glińska-Neweś, Sudolska, Karwacki, and Górka (2017) write in a similar context about the essence of innovation. In their opinion, "innovation is every result of human activities contributing to the improvement of human life quality; every activity which enables one to act better, more efficiently, more effectively."

Directly linked to the previous aspect of defining innovation is their perception through the use of knowledge (see Carter and Willams, 1958; Kuznets, 1959; Urbancová, 2013). Innovations undoubtedly result from combining the knowledge, skills, abilities, and creativity of the human factor with organizational or technological possibilities or the growing needs of clients. Moreover, Silverberg and Soete (1994) recognize the relationship between the level of knowledge and training of employees and the potential and innovative possibilities of the company. Furthermore, they emphasize the significance of expenditures allocated by economic entities to research and development, along with systematic investments in human capital. One of the more adequate definitions for this dimension of innovation is formulated by Szczepańska-Woszczyna (2016), according to whom innovation is "a process of development and application of knowledge, which involves changes in both technical and social structures, and requires a cumulative learning process for producers and users." Szczepańska-Woszczyna emphasizes not only the expansion of internal knowledge in the enterprise to create innovation but also the possibility of gaining and broadening horizons or the ability to create the needs of recipients for innovative products and services.

An extremely valuable study is the work of Baregheh, Rowley, and Sambrook (2009), who combine many definitions of innovation from various disciplines of knowledge. 
Definitions presented in their article date from the period 1934-2007 and come from seven various disciplines: business and management; economics; organization studies; innovation and entrepreneurship; technology, science, and engineering; knowledge management; and marketing. After a thorough analysis of 60 different approaches to innovation, the authors propose a comprehensive multidisciplinary definition that aptly reflects the nature of modern innovation processes: "innovation is the multi-stage process whereby organizations transform ideas into new/improved products, service or processes, in order to advance, compete and differentiate themselves successfully in their marketplace."

While undertaking research in the area of innovative activity of enterprises, it is generally recommended to base on the terminology adopted by the Organisation for Economic Co-operation and Development in the international methodological compendium in the field of innovation research, which states that innovation is "to implement in business practice a new or significantly improved solution, which redefines the way the company works or relations with the environment" (OECD, 2008). OECD specialists formulate a broad definition of innovation that covers several of the abovementioned threads: the aspect of the practical use of new products; first use and the significant modernization of a solution; the plane of changes occurring both in the organization and in its contacts with the external environment.

\section{Materials and Methods}

The subject of the current study covered small and medium-sized enterprises distinguished in the Ranking of Polish Business Gazelles 2018. The concept of entrepreneurial companies called gazelles was introduced by D. Birch - even though it appeared in the 1990s - is still used in many scientific studies (see Markman and Gartner, 2002; Delamr, Davidsson, and Gartner, 2003; Henrekson and Johansson, 2008; Davidsson, Steffens, and Fitzsimmons, 2009; Heimonen, 2012) and as the basis for creating rankings of economic activities effectiveness. For the last eighteen years, Coface Poland's business intelligence agency prepares an annual ranking for the daily Puls Biznesu: in 2018, they awarded 4500 entities as winners. Although the conditions for the function of the organization change over the years, the criteria for preparing the Business Gazelles Report remain unchanged: 
1) conducting business operations for a minimum of three years;

2) achieving in the base year ${ }^{3}$ sales revenues between PLN 3-200 million;

3) achieving year-on-year revenue growth in the last three years.

It analyzes the results of enterprises based on shared financial documents for the three full years preceding the ranking (Kraśnicka, Głód, and Wronka-Pośpiech, 2016). The position occupied by the company on the winners' list is determined by the increase in the percentage of turnover achieved in the three analyzed years. ${ }^{4}$ The research sample was determined arbitrarily and contained innovative economic entities belonging to the SME sector that developed dynamically in the recent three years on the Polish market.

Research using the Computer Assisted Web Interviews (CAWI) was conducted under the guideline of the research procedure of the innovation audit creators, Tidd and Bessant (2013). The electronic questionnaire was sent to selected enterprises from the SME sector $(n=110)$ in December 2018. The table below presents the structure of surveyed companies according to their size, head office voivodeship, and the type of business activity according to the sections of the Polish Classification of Activities (PKD) and its affiliation to the Information and Communication Technology Sector (ICT).

The adopted sample is dominated by small enterprises (that hire 10-49 employees), which account for $53 \%$ of the surveyed entities. Other companies (47\%) are of medium size (that hire 50-250 employees). While analyzing the location of their headquarters, data from all sixteen voivodeships were obtained; however, most enterprises operate in the Kuyavian-Pomeranian and Masovian voivodeships, as these regions accounted for nearly half of the examined sample. Such a high percentage of enterprises from the above two voivodeships results, in the case of Kuyavian-Pomeranian, from my proximity to and possibility of direct contact with managers and, in the case of Masovian, with more entrepreneurs who are more willing to partake in an innovation audit. Taking into account the penultimate element of sample characteristics - i.e. the type of business activity according to the PKD sections - the research examined enterprises from the majority of possible areas of activity (13 out of 21 sections). The largest group of respondents were entrepreneurs involved in industrial processing (section C: 38 entities), information and communication activities (section J: 34 entities), and wholesale and retail trade (section G: 16 entities). Significant from the viewpoint of conducted observations is the separation of results for enterprises that operate in the ICT sector,

The base year is calculated according to the rule (x-3), i.e. for the 2018 ranking, the base year is 2015.

In the analyzed case, this will be data from 2017 vs. 2015. 
which accounted for one-third of the sample, against the results achieved by companies operating outside of the ICT sector, which made up $66 \%$ of the surveyed entities. Noteworthy, service companies approached the innovation audit with greater involvement than production companies.

Table 1. Structure of the surveyed entities $(n=110)$

\section{Criterion}

Percentage share

\section{Company size:}

Small

Medium-sized

Location of the company:

Lower Silesian Voivodeship

Kuyavian-Pomeranian Voivodeship

Lublin Voivodeship

Lubuskie Voivodeship

Łódź Voivodeship

Lesser Poland Voivodeship

Masovian Voivodeship

Opole Voivodeship

Subcarpathian Voivodeship

Podlaskie Voivodeship

Pomeranian Voivodeship

Silesian Voivodeship

Świętokrzyskie Voivodeship

Warmian-Masurian Voivodeship

Greater Poland Voivodeship

West Pomeranian Voivodeship

\section{Sections by PKD:}

$\mathrm{C}-$ Industrial processing

D - Production and supply for electric energy, gas, water stage, hot water, and air for air conditioning systems 


\begin{tabular}{|l|r|}
\hline F - Architecture & 1.8 \\
\hline $\begin{array}{l}\text { G - Wholesale and retail trade; repair of motor vehicles, } \\
\text { including motorcycles }\end{array}$ & 14.6 \\
\hline H - Transport and storage & 3.6 \\
\hline I - Activity related to accommodation and catering service & 0.9 \\
\hline J - Information and communication & 31.0 \\
\hline K - Financial and insurance activities & 2.7 \\
\hline L - Real estate activities & 0.9 \\
\hline M - Professional, scientific, and technical activity & 3.6 \\
\hline N - Administration and support activities & 2.7 \\
\hline R - Activities related to culture, entertainment, and recreation & 1.8 \\
\hline S - Other service activities & 0.9 \\
\hline Belonging to the ICT sector: & \\
\hline Entities from the ICT sector & 33.6 \\
\hline Entities not from the ICT sector & 66.4 \\
\hline
\end{tabular}

Source: own elaboration based on own research.

\section{Research Results}

The analysis of enterprise innovativeness, using the audit procedure proposed by Tidd and Bessant (2013, pp. 634-637) allows me to show in an accessible and transparent manner the pro-innovative attitude and the level of implementation of "the new" in five basic areas of business entities: strategy, processes, organization, connections, and learning. The distinguished areas contain elements of currently dominant concepts of organization management: the necessity of continuous development of key competences, openness to new solutions, the need to establish deeper and more lasting relationships in the field of creating innovation, and the ability to creatively combine company potentials with opportunities in the near and distant market environments. I know that the presented method has limitations and is only a general outline of the current situation in a company based on declarative indications of owners, which refer to the use of innovation in their firms. However, this approach can be a successful starting point for further in-depth analysis by management in less-rated areas.

The result of the innovation audit performed on 110 Polish enterprises from the SME sector is presented in four perspectives: general (Figure 2), regional (Figure 3), sectoral 
(Figure 4), and considering the enterprises by size - separately for small and medium-sized business entities (Figure 5). The results presented on radar diagrams include the average rating of a group of statements according to the seven-point ordinal scale, in which 1 means "I completely disagree;" 2 - "I disagree;" 3 - "I slightly disagree;" 4 - "I have no opinion;" 5 - "I slightly agree;" 6 - "I agree;" 7 - "I completely agree."

Figure 2. Innovation audit of investigated Polish Business Gazelles $(n=110)$

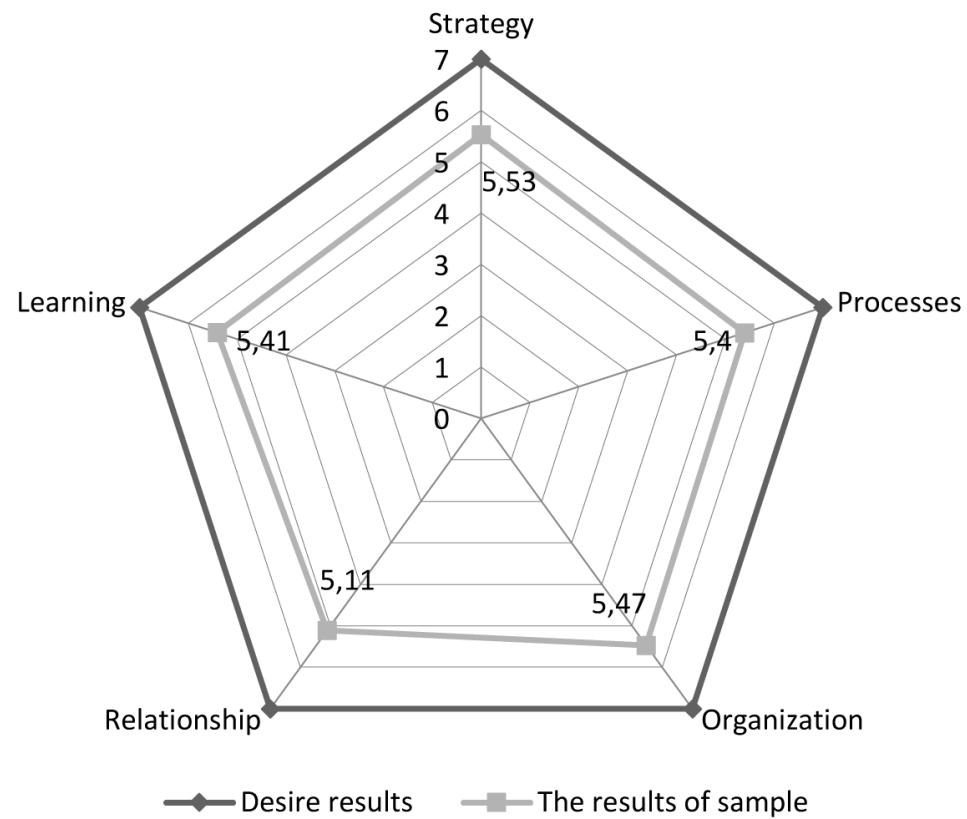

Source: own elaboration of the research.

The level of innovation among the surveyed Polish Business Gazelles was in general relatively satisfactory. In all the mentioned areas, the average score fluctuated between 5.11 and 5.53. In the examined sample, the issues of strategy and organization were rated the highest; in both cases, the average of indications appears in the vicinity of 5.5 to 7 points. This means that the analyzed companies know of creating and implementing innovative strategies, which is identified not only by owners and management but also by lower-level employees. The questionnaire repeatedly stressed that the creation of an appropriate organizational structure combined with a proper climate supports creativity in the workplace and translates into the greater involvement of employees and the use of individual resources to create key competitive advantage. The respondents rated slightly lower - at 5.4 points - two other audit areas, i.e. processes and learning. Efficient and effective process management, the use of innovative solutions, along 
with systematic training and absorption of knowledge from other entities, were identified as one of the most frequently implemented activities by the owners in the studied areas. The owners notice the necessity of focusing on the multifaceted development of the organization, taking into account the technological and social changes that happen in the work environment. The lowest rated issues were connections that are cooperation with other entities and networking in the field of creating and implementing innovative solutions. For many years, the weakness of smaller business entities in Poland was establishing cooperation in the field of innovative activity. Both the level and scope of this cooperation is at a low and unsatisfactory level (see Drews, 2017).

In the surveyed sample, almost half of the enterprises had their headquarters in the Kuyavian-Pomeranian and Masovian Voivodeship. Therefore, it seems reasonable to compare the level of innovativeness of economic entities from the perspective of both regions and then compare them to the average obtained from other voivodeship. Figure 2 shows that entities from Kujawy and Pomerania slightly diverge in most studied areas - except learning - from the grades obtained in Masovia and other provinces. On the one hand, this state of affairs may result from entrepreneurs' awareness of their weaknesses and barriers in implementing innovative solutions or, on the other hand, from the lower level of entrepreneurial orientation of business entities in the region. This is by the annual reports of the Polish Agency for Enterprise Development, in which the Kuyavian-Pomeranian region placed in the middle of the ranking for 2019 (Nieć, 2018). The most significant differences between the analyzed regions occur in the function of the innovative organizational system. The highest average marks, 5.73, were obtained by Masovian enterprises, which highly assessed employees' and board's involvement in creating the innovative process, the favorable pro-development climate in the company, and the efficiency of communication channels or teamwork. We may assume that the enterprises that operate in the Masovian Voivodeship are characterized by a higher level of development and organizational awareness of companies from other regions. This state of affairs may occur in their functioning in a more advanced business infrastructure. The above assumptions confirm the attitude of companies from outside of Masovia, mainly in the creation of coherent innovation strategies - an area in which other regions obtained the highest ratings - and the development of procedures and tools to analyze the impact of individual expansion factors. Only after creating a compatible strategy with the company's vision can enterprises focus on the issues of organization and application of effective process solutions. Regardless of the region, the area rated the lowest by most respondents was relationship.

Another area of interest in the conducted innovation audit is the business sector of the surveyed Business Gazelles. Due to the high percentage of companies that operate 
in the modern telecommunications infrastructure sector - mainly software-related activities -I divided the companies into those belonging to the ICT sector ( $34 \%$ of all entities) and those operating outside of this sector (66\% of all entities). Enterprises that operate within the ICT sector received significantly higher ratings in all analyzed areas of innovation audit than companies from other sectors of the economy; on average, by 0.4 percentage points. The largest differences were noted in the area of connections, i.e. companies that offer modern solutions in the field of information and communication much more often establish relationship and cooperation regarding the implementation of innovative projects. Moreover, they more often undertake interaction with higher education institutions or research and development centers. We may assume that closer attention to innovative issues in enterprises from the ICT sector is directly related to the functioning of this industry, which obliges and internally stimulates its diversification of innovative activities. The most attention of enterprises from the ICT sector is devoted to the creation of organizational structures supporting creativity. On the other hand, companies that do not belong to the ICT sector undertake activities aimed at planning and implementing an innovative strategy, but also learning and adapting proven solutions from more technologically advanced entities.

Figure 3. A regional approach to the results of the innovation audit $(n=110)$

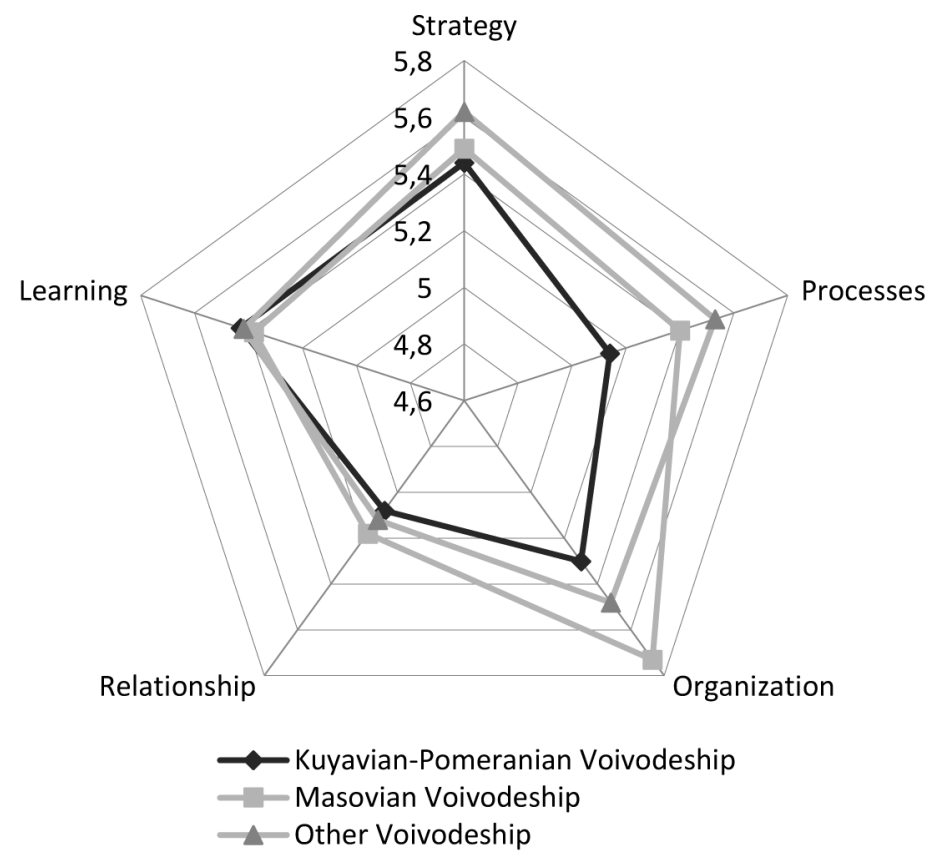

Source: own elaboration of the research. 
The ICT sector is currently the key pillar of the knowledge-based economy, whose development became a priority challenge for many countries, including Poland (Strożek and Jewczak, 2016). Scholars foreground that the Polish ICT industry can become a showcase of the native economy against the background of the entire region of Central and Eastern Europe. Polish ICT industry occupies the fifth place among European countries in terms of the number of registered enterprises from the ICT sector, which proves the high potential of this sector for both economic growth and employment (Ministerstwo Rozwoju, 2017). Moreover, this sector is decisively stimulating the so-called digital transformation of the entire economy, which affects the rapid improvement in the performance level of other sectors.

Figure 4. A sectoral approach to the results of the innovation audit $(n=110)$

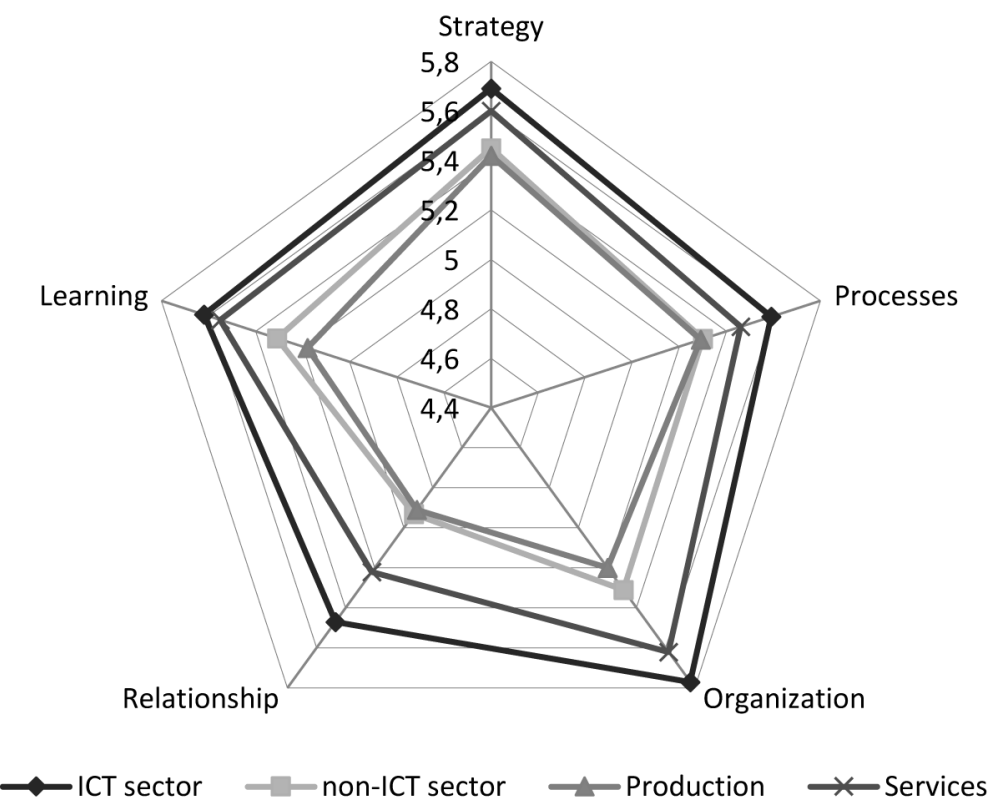

Source: own elaboration of the research.

Similarly, a significant difference in the tested areas of innovation is visible when - among Business Gazelles - we distinguish production companies (36\% of all entities) and companies offering broadly understood services (64\% of all entities). It would seem that strictly production-oriented companies have greater possibilities in the field of introducing innovative ideas and creating an intra-organizational climate conducive to new products. Nevertheless, it is in service companies that all areas of the innovation audit have been rated higher; on average, by 0.3 percentage points. This state of affairs may be a consequence of the services sector development dynamics, and thus the need 
to diversify and modernize the methods used and to adapt existing solutions to changing customer preferences and market trends. In production enterprises, more activities are conducted in the area of strategic goals and improvement of functioning organizational processes than in the case of service companies

Figure 5. Innovation audit from the perspective of the size of companies $(n=110)$

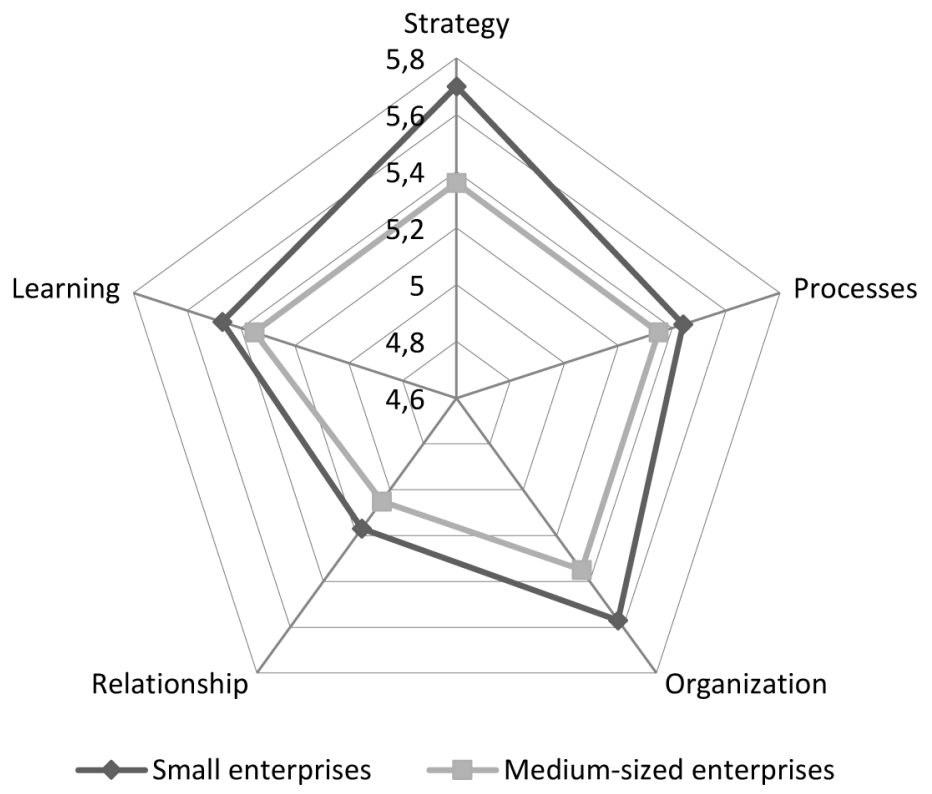

Source: own elaboration of the research.

The last issue analyzed here is the overview of the innovation audit by the size of companies. Figure 4 shows the differences between individual areas of innovation. The examined small business entities devote much more attention to the creation of flexible and effective organizational structures; they more often analyze completed projects and draw conclusions from them for the future rather than medium-sized enterprises. Certainly, this is related to the fact that "learning from own mistakes" costs smaller companies much more time and financial resources than larger companies, which have both. However, it may be positive that most respondents agree with the presented statements, as evidenced by the range of applied ratings: 5.05-5.36 among medium-sized companies and between 5.17-5.70 among small business owners. Nevertheless, the distribution of assessed areas of innovation is similar for both groups of entrepreneurs: most important is the right development strategy, efficient communication flow in the company, and support to innovation-friendly climate. Both small and medium-sized entrepreneurs emphasized the importance of involving human capital (employees 
and managerial staff) in the development of their companies' innovation. Relationship was again rated by respondents the lowest. Small business owners also rated low the area of processes. In turn, for owners of medium-sized business entities the area of learning is of little importance. Such an answer structure may be related to the specificity of the functioning of enterprises of various sizes. Unfortunately, the owners of small enterprises often identify the meaning of the company's existence through the prism of economic functions - generating revenues from sales and increasing profits - and not from the viewpoint of innovative or social functions of the company (Orłowski et al., 2010). Due to limited resources, small entities do not have in their structures elements like R\&D departments that would improve the mechanisms for managing process changes, systems for selecting the most profitable investment projects, or solutions that ensure the systematic and effective search for ideas in new products or services.

\section{Conclusion}

The main interpretive elements of "innovation" presented in this article confirm the multifaceted nature of this notion, but also the existence of connections between them. As indicated by numerous studies conducted on the examples of Polish SME's, the perspective of their perception of innovation shows an internal contradiction that, on the one hand, affirms innovation as the primary source of income but, on the other hand, shows significant risk due to the necessity of assigning additional expenses for this purpose (see Szopik-Depczyńska, 2015; Sachpazidu-Wójcicka, 2017; Zygmunt, 2017; Lewandowska and Stopa, 2018). The above theoretical considerations, supplemented with the results of empirical research, allow me to formulate several conclusions:

- current directions of scientific research and pioneering activities in companies emphasize innovation, entrepreneurship, and the creation of unique competitive advantages in the form of resources, competencies, or abilities;

- the conducted innovation audit showed a relatively satisfactory level in the use of innovative methods and solutions in strategy, processes, organization, relationship, and learning as the average results of statements in all areas ranged $5.20-5.63$;

- owners of small and medium-sized enterprises included in the Polish Business Gazelles 2018 ranking know that the systematic operation of innovative activities is a determinant of the competitiveness of modern business;

- differences in the innovation orientation of the surveyed entities are not so significant in the regional approach, as definitely higher disproportions in the assessed areas occur in the analysis of enterprises by size and business sector; 
- respondents often emphasized the importance of human resources - their experience, competences, attitudes - in the process of creating and implementing innovative solutions, which ultimately bear the overall development and success of the company on the market.

I am aware that the above considerations, based solely on the quantitative analysis of a part of the population of Polish Business Gazelles, do not exhaust the discussed issues. However, the current study can be the basis for further qualitative research on the factors that stimulate and limit innovation activity conducted by companies.

\section{References}

Allen, J.A. (1966). Scientific Innovation and industrial prosperity. London: Longman.

Barnett, H. (1953). Innovation. The Basis of Cultural Change. New York: McGraw-Hill.

Baregheh, A. and Rowley and J., Smabrook, S. (2009), Towards a Multidisciplinary Definition of Innovation. Management Decision, 47(8), 1323-1339, http://dx.doi.org/10.1108/002517409109 84578.

Białoń, L. (2010). Zarzqdzanie działalnościq innowacyjnq. Warszawa: Wydawnictwo Placet.

Bogdanienko, J., Haffer, M. and Popławski, W. (2004). Innowacyjność przedsiębiorstw. Toruń: Wydawnictwo Uniwersytetu Mikołaja Kopernika w Toruniu.

Borins, S. (2002). Leadership and innovation in public sector. Leadership \& Organization Development Journal, 23(8), 467-476, http://dx.doi.org/10.1108/01437730210449357.

Brown, T.E. and Ulijn, M.J. (2004). Innovation, entrepreneurship and culture: The interactive between technology, progress and economic growth. Northampton: Edward Elgar.

Brzeziński, M. (2001). Zarzqdzanie innowacjami technicznymi i organizacyjnymi. Warszawa: Difin.

Carter, C.F. and Willams, B.R. (1958). Industry and Technological Process. London: Oxford University Press.

Damanpour, F. (1991). Organizational innovation: A Meta Analysis of Effects of Determinants and Moderators. Academy of Management Journal, 34(3), 555-590, http://dx.doi.org/10.2307/256406.

Davidsson, P., Steffens, P. and Fitzsimmons, J. (2009). Growing Profitable or Growing from Profits: Putting the Horse in Front of the Cart? Journal of Business Venturing, 24(4), 388-406, http://dx.doi.org/10.2139/ssrn.1263088.

Delmar, F. Davidsson, P. and Gartner, W.B. (2003). Arriving at the High-growth Firm. Journal of Business Venturing, 18(2), 189-216, http://dx.doi.org/10.1016/S0883-9026(02)00080-0.

Dolińska, M. (2012). Activity of Companies in Innovation Networks. Equilibrium. Quarterly Journal of Economics and Economic Science, 7(1), 21-31, http://doi.org/10.12775/EQUIL.2012.002.

Drews, A. (2017). Kooperacja małych przedsiębiorstw w zakresie działalności innowacyjnej. Research on Enterprise in Modern Economy: Theory and Practise, 22(3), 39-53, http://doi.org/10.19253/reme.2017.03.003.

Drucker, P.F. (1994). Innowacja i przedsiębiorczość. Praktyka i zasady. Warszawa: Polskie Wydawnictwo Ekonomiczne.

Freeman, Ch. (1997). The Economic of Industrial Innovation. London: Continuum.

Glińska-Neweś, A., Sudolska, A., Karwacki, A. and Górka, J. (2017). Innovation among people: how positive relationship at work can trigger innovation creation, E\&M Economics and Management, 20(3), 84-100, https://dx.doi.org/10.15240/tul/001/2017-3-006. 
Griffin, R.W. (1996). Podstawy zarzqdzania organizacjami. Warszawa: PWN.

Greenhalgh, T., Glenn, R., Fraser, M., Bate, P. and Kyriakidou, O. (2004). Diffusion of innovations in service organizations: systematic review and recommendations. Milbank Quarterly, 82(4), 581-629, http://doi.org/10.1111/j.0887-378X.2004.00325.x.

Grudzewski, W.M. and Hejduk, I.K. (2000). Przedsiębiorstwo przyszłości. Warszawa: Difin.

Gust-Bardon, N.I. (2012). Innowacja w myśli ekonomicznej od XVIII do XX wieku: analiza wybranych zagadnień. Acta Universitatis Nicolai Copernici: Ekonomia, 43(1), 105-120, http://doi.org/10.12775/AUNC_EKON.2012.008.

Harman, A. (1971). The International Computer Industry. Innovation and Comparative Advantage. Cambridge: Harvard University Press.

Heimonen, T. (2012). What Are the Factors that Affect Innovation in Growing SMEs? European Journal of Innovation Management, 15(1), 122-144, https://doi.org/10.1108/14601061211192861.

Henrekson, M. and Johansson, D. (2008). Gazelles as Job Creators - a Survey and Interpretation of the Evidence. Stockholm: Research Institute of Industrial Economics. Sweden IFN Working Paper no. 733, 1-28.

Holstein-Beck, M. (1977). Problemy kierowania postępem. In: S. Kowalewski (ed.), Socjalistyczna teoria organizacji: koncepcje - kierunki. Warszawa: Polskie Wydawnictwo Ekonomiczne.

Janasz, W. (2005). Innowacje $w$ działalności przedsiębiorstw w integracji z UE. Warszawa: Difin.

Jurczyk-Bunkowska, M. (2014). Istota innowacyjności i jej cele. In: R. Knosala et al. (eds.), Zarzqdzanie innowacjami. Warszawa: Polskie Wydawnictwo Ekonomiczne.

Kasprzyk, S. (1980). Innowacje. Od koncepcji do produkcji. Warszawa: Instytut Wydawniczy Centralnej Rady Związków Zawodowych.

Kotarba, W. (1987). Organizacja wynalazczości w przedsiębiorstwie. Warszawa: Zrzeszenie Wojewódzkich Klubów Techniki i Racjonalizacji.

Kotler, Ph. (1999). Marketing. Analiza, planowanie, wdrażanie i kontrola. Warszawa: Felberg SJA.

Kraśnicka, T., Głód, W. and Wronka-Pośpiech, M. (2016). Innowacyjność polskich gazel biznesu. Studia Ekonomiczne. Zeszyty Naukowe Uniwersytetu Ekonomicznego w Katowicach, 270, 132-142.

Kuznets, S. (1959). Six Lectures on Economic Growth. Chicago: Free Press.

Lewandowska, A. and Stopa, M. (2018). SMEs innovativeness and institutional support system: the local experiences in qualitative perspective. Polish case study. Oeconomia Copernicana, 9(2), 333-351, http://doi.org/10.24136/oc.2018.017.

Madej, Z. (1970). Nauka i rozwój gospodarczy. Warszawa: Polskie Wydawnictwo Ekonomiczne.

Markman, G.D. and Gartner, W.B. (2002). Is Extraordinary Growth Profitable? A Study of Inc. 500 High-Growth Companies. Entrepreneurship Theory and Practice, 27(1), 65-75, http://doi.org/10.1111/1540-8520.t01-2-00004.

Marshall, A. (1920). Industrial Organization, The concentration of Specialized Industries in Particular Localities. In: A. Marshall (ed.), Principles of Economics, 8th edition. London: MacMillan and Co.

Mill, J.S. (1848). Principles of Political Economy. Indianapolis/Cambridge: Hackett Publishing.

Ministerstwo Rozwoju (2017). Perspektywy rozwoju polskiej branży ICT do roku 2025. Warszawa: Polska Agencja Rozwoju Przedsiębiorczości.

Nieć, M. (2018). Ranking przedsiębiorczości w układzie wojewódzkim. Wskaźnik syntetyczny. In: A. Skowrońska and A. Tarnawa (eds.), Raport o stanie sektora małych i średnich przedsiębiorstw w Polsce. Warszawa: Polska Agencja Rozwoju Przedsiębiorczości.

Niedzielski, P. (2003). Polityka innowacyjna w transporcie. Szczecin: Wydawnictwo Uniwersytetu Szczecińskiego. 
Niedzielski, P. and Łobacz, K. (2011). Istota współczesnych innowacji - specyfika, kierunki, trendy. In: J. Perenc and J. Hołub-Iwan, J. (eds.), Innowacje w rozwijaniu konkurencyjności firm. Znaczenie, wsparcie, przykłady zastosowań. Warszawa: Wydawnictwo C.H. Beck.

OECD (2008). Podręcznik Oslo. Zasady gromadzenia i interpretacji danych dotyczacych innowacji. Warszawa: Wydawnictwo Ministerstwa Nauki i Szkolnictwa Wyższego.

Open Science Centre (2018). http://yadda.icm.edu.pl/yadda/search/innovation.all.

Orłowski, W., Pasternak, R., Flaht, K. and Szubert, D. (2010). Procesy inwestycyjne i strategie przedsiębiorstw w czasach kryzysu. Warszawa: Polska Agencja Rozwoju Przedsiębiorczości.

O’Sullivan D. and Dooley, L. (2009). Applying Innovation. California: Sage Publishing.

Parker, J.E.S. (1974). The Economics of innovation. The national and multinational enterprise in technological change. London: Longman.

Penc, J. (1999). Innowacje i zmiany w firmie. Transformacja i sterowanie rozwojem przedsiębiorstwa. Zasady działania. Warunki sukcesu. Warszawa: Wydawnictwo Placet.

Pietrasiński, Z. (1970). Ogólne i psychologiczne zagadnienia innowacji. Warszawa: Polskie Wydawnictwo Ekonomiczne.

Pigou, A.C. (1932). The Economics of Welfare. London: Macmillan and Co.

Pomykalski, A. (2001). Zarzqdzanie innowacjami. Warszawa: Polskie Wydawnictwo Ekonomiczne.

Porter, M.E. (1990). The Competitive Advantage of Nations. London: The Macmillan Press.

Ricardo, D. (1821). On the Principles of Political Economy and Taxation. London: John Murray.

Rogers, E.M. (2003). Diffusion of innovations. New York: Free Press.

Rothwell, R. (1986). Public Innovation Policy: To Have Or To Have Not? R\&D Management, 16(1), 34-63, http://doi.org/10.1111/j.1467-9310.1986.tb01154.x.

Sachpazidu-Wójcicka, K. (2017). Innovation as a determinant of the competitiveness of Polish enterprises. Oeconomia Copernicana, 8(2), 301-316, http://doi.org/10.24136/oc.v8i2.18.

Say, J.B. (1855). Of the Labour of Mankind of Nature and of Machinery Respectively. In: C.C. Biddle (ed.), A Treatise on Political Economy. Philadelphia Grambo \& Co., http://www.econlib.org/library/Say/sayT7.html.

Siau, K. and Messersmith, J. (2003). Analyzing ERP implementation at a public University using the innovation strategy model. International Journal of Human-Computer Interaction, 16(1), 57-80, http://doi.org/10.1207/S15327590IJHC1601_5.

Schumpeter, J.A. (1960). Teoria rozwoju gospodarczego. Warszawa: Polskie Wydawnictwo Naukowe.

Silverberg, G. and Soete, L. (1994). The Economics of Growth and Technical Change. Brookfield: Edward Elgar.

Smith, A. (1904). Of the Division of Labour. In: E. Canaan (ed.), An Inquiry into the Nature and Causes of the Wealth of Nations. London: Methuen \& Co.

Stamm, B. (2008). Managing Innovation, Design and Creativity. Chichester: John Wiley \& Sons Ltd.

Strożek, P. and Jewczak, M. (2016). Rozwój sektora ICT w Polsce - ocena międzyregionalna. Zeszyty Naukowe Uniwersytetu Ekonomicznego w Krakowie, 9(957), 101-117, http://doi.org/10.15678/ZNUEK.2016.0957.0907.

Szczepańska-Woszczyna, K. (2016). Kompetencje menedżerskie w kontekście innowacyjności przedsiębiorstwa. Warszawa: Polskie Wydawnictwo Naukowe.

Szopik-Depczyńska, K. (2015). Effects of Innovation Activity in Industrial Enterprises in Eastern Poland. Oeconomia Copernicana, 6(2), 53-65, http://doi.org/10.12775/OeC.2015.012.

Tarde, G. (1902). L’invention considereee comme, moteur de l'evolution sociale. Reveu Internationale de Sociologie, 7, 561-574. 
Tidd, J. and Bessant, J. (2013). Managing Innovation. Integrating Technological, Market and Organizational Change. London: John Wiley \& Sons, Ltd.

Timmerman, J.C. (2009). A Systematic Approach for Making Innovation a Core Competency. The Journal for Quality and Participation, 31(4), 4-10.

Tokarski, J. (1971). Słownik wyrazów obcych. Warszawa: Wydawnictwo Naukowe PWN.

Urabe, K. (1988). Innovation under Japanese management. In: K. Urabe, J. Child and T. Kagono (eds.), Innovation and Management. Berlin Walter de Gruyter.

Urbancová, H. (2013), Competitve Advantage Achievement through Innovation and Knowledge, Journal of Competitiveness, 5(1), 82-96, http://doi.org/10.7441/joc.2013.01.06.

Walker, R.M. (2006). Innovation type and diffusion: An empirical analysis of local government. Public Administration, 84(2), 311-335, http://doi.org/10.1111/j.1467-9299.2006.00004.x.

Wandelt, K. (1972). Studia nad postępem technicznym i organizacyjnym. Poznań: Poznańskie Towarzystwo Przyjaciół Nauk.

Webber, R.A. (1996). Zasady zarzq̨dzania organizacjami. Warszawa: Polskie Wydawnictwo Ekonomiczne.

Whitfield, P.R. (1979). Innowacje w przemyśle. Warszawa: Polskie Wydawnictwo Ekonomiczne.

Więckowski, J. and Pasieczny, L. (1981). Ekonomika przedsiębiorstwa. Warszawa: Polskie Wydawnictwo Ekonomiczne.

Wildowicz-Giegel, A. (2012). Intellectual Capital and Innovativeness of Polish Enterprises in the context of Europe 2020 Strategy Goals. Equilibrium. Quarterly Journal of Economics and Economic Science, 7(1), 33-45, http://doi.org/10.12775/EQUIL.2012.003.

Witkowska, J. and Wysokińska, Z. (2006). Umiędzynarodowienie małych i średnich przedsiębiorstw a procesy integracji europejskiej. Aspekty teoretyczne i empiryczne. Łódź: Wydawnictwo Uniwersytetu Łódzkiego.

Zastempowski, M. (2010). Uwarunkowania budowy potencjału innowacyjnego polskich małych i średnich przedsiębiorstw. Toruń: Wydawnictwo Naukowe Uniwersytetu Mikołaja Kopernika w Toruniu.

Zygmunt, A. (2017). Innovation activities of Polish firms. Multivariate analysis of the moderate innovator countries. Oeconomia Copernicana, 8(4), 505-521, http://doi.org/10.24136/oc.v8i4.31.

Żołnierski, A. (2005). Potencjał innowacyjny polskich małych i średnich przedsiębiorstw. Warszawa: Polska Agencja Rozwoju Przedsiębiorczości. 